\title{
The Impacts of Climate Variability on the Wind Erosion Potentials in the Western Region of Makran Coastal Plain, Iran
}

Mohammad Akbarian ( $\nabla$ m.akbarian@hormozgan.ac.ir)

University of Hormozgan https://orcid.org/0000-0002-8014-0921

Asadollah Khoorani

University of Hormozgan

\section{Research Article}

Keywords: climatic change, environmental hazards, Hormozgan Province, sand dune, trending

Posted Date: July 13th, 2021

DOI: https://doi.org/10.21203/rs.3.rs-628031/v1

License: (c) (1) This work is licensed under a Creative Commons Attribution 4.0 International License.

Read Full License 


\title{
The Impacts of Climate Variability on the Wind Erosion Potentials in the Western Region of Makran Coastal Plain, Iran
}

Corresponding Author: Mohammad Akbarian ${ }^{1}$ Assistant professor of Physical Geography, University of Hormozgan, Bandarabbas, Iran, Tell: +989173680966, E-mail: m.akbarian@hormozgan.ac.ir; ORCD ID: 00000002-8014-0921

Asadollah Khoorani Associate professor of Physical Geography, University of Hormozgan, Bandarabbas, Iran, Tell: +9891124803242, E-mail: khoorani@hormozgan.ac.ir; ORCID ID: 0000-0003-0311-9624

\begin{abstract}
Coastal plains are prone to various degrees of wind erosion due to their characteristics. This study aimed to investigate the effect of climatic factors in the western region of Makran coastal plain in a southeastern region of Iran on the wind erosion potential. The study period was 1993-2018. First, the data related to wind velocities, relative humidity and precipitation, and the granulometric data of plain surface sediments were obtained. Then, the wind erosion threshold velocity in humid air conditions was determined. Finally, the Mann-Kendall test was applied to analyze the probability of wind erosion and its temporal variability. The results indicated that the wind erosion threshold, in terms of humidity changes, varied from 7.21 to 12.31 meters per second during the study period. The highest probability of wind erosion was in February, March, and April, with 24.69\%, 21.51\%, and 20.41\%, respectively. The lowest probability of wind erosion was in October, November, and September with 4.00\%, 4.12\%, and $6.00 \%$, respectively. Finally, the erosion trend analysis indicated that wind erosion was a temporal phenomenon that increased significantly in January (winter solstice) and July (summer solstice). These months were characterized by an increase in the wind blowing at speed above the threshold. Otherwise, the months were not different from other months of the year in terms of precipitation or the number of dry days. Therefore, wind erosion is expected to maximize in the early winter and the early summer.
\end{abstract}

Keywords: climatic change, environmental hazards, Hormozgan Province, sand dune, trending

${ }^{1}$ Corresponding Author 


\section{Introduction}

Soil's resistance to erosion depends on many factors such as slope steepness, topographic position, and the amount of disturbance. Nevertheless, the properties of soil texture are the most crucial determinants (Morgan, 2009). Experiments have revealed that wind velocities of up to 4.5 meters per second can be considered an erosive factor in dry areas. From this point on, changes in the wind erosion rates are followed by changes in velocities (Mahmoudi, 2002). In other words, the transport of sediment by the wind results from the interaction between the wind and the earth's surface, which depends on the size of the sediment grains (Bagnold, 1941), soil moisture, and other soil erodibility factors(Wilson \& cook,1980). According to Bagnold (1941), only the minimum threshold velocity is necessary to move the grain of $0.15 \mathrm{~mm}$ in size; In other words, the particles of $0.15 \mathrm{~mm}$ in size have a tremendous mobility potential. Above and below this size, the threshold velocities increase more rapidly in proportion to the square root of particle diameter. Once the movement exceeds the fluidity threshold and the grains are moved, the threshold velocity can be reduced to the compression dividing line without changing the moving load (Chorly et al., 2000). In addition to the surface soil characteristics, the sources of soil moisture from the atmosphere are the main factors affecting wind erosion (Shayan et al., 2014). A climatic condition affecting wind erosion factors includes threshold velocity, rainfall, evapotranspiration, relative humidity, and temperature (Cornelis, 2006). The alternation of each of these factors can be negative or positive on wind erosion potentiality.

Meanwhile, rain has a unique effect on wind erosion, as only the dry soils are eroded, and the wet soils cannot be moved by the wind (Refahi, 2004). Rainfall and evapotranspiration alter soil erosion by changing the soil moisture status. It should be noted that although the kinetic energy of raindrops on the wind erosion is not considered, the destruction of colloids from the surface soil between two rain provides the conditions for the transportation of splashed grains similar to splashes in water erosion (Cornelis et al., 2004). However, the effects of precipitation on reducing wind erosion are not negligible. Studies have indicated that if the dry soil is soaked to the point of permanent wilting, its erosion slows down initially and then decreases rapidly (Refahi, 2004, Chepil, 1956; Bisal \& Hesiyeh, 1966).

Although wind erosion is a global phenomenon, its severity depends on environmental circumstances (Chorley et al., 2000). Coastal regions, like the arid lands, are affected by the wind. Besides, dunes are an integral part of our coastal environment (Kidd, 2001); the environmental conditions have pushed the wind to be the main factor of the desertification process in the arid and semi-arid regions (Yan, 2004). So in coastal zones, arid climatic conditions made wind erosion and process more complex (Mahmoudi, 1995). The coast is a zone where the lithosphere, hydrosphere, and atmosphere meet and interact (Bird, 2008). It is also a highly extraordinary physical energy and biological diversity (Murthy et al., 2002). Although small populations live in arid regions of the world, almost half of the world's population lives in coastal areas (Bird, 2008). Due to the importance of wind erosion in the arid and coastal regions (Bagnold, 1941; Chepil et al., 1963; Greeley et al., 1985); The erosion of sandy beaches and coastal dunes is a general engineering problem, which has attracted the interest of many researchers, including Steetzel (1993), Larson et al. (2004), and Rijn (2013). Asakareh et al. (2015) studied the wind erosion potential in Khuzestan province, Iran; Using the data from 58 weather stations from 1987 to 2010, they calculated the threshold velocities of different soil textures and determined the probability of erosion in dry and wet conditions. Khoshakhlagh et al. 
(2017) investigated the impact of global warming on wind erosion in central Iran. Shen et al. (2018) studied the statistical characteristics of the wind-erosion events in northern China. They analyzed the wind speed data from 1980 to 2015 from 51 meteorological stations and classified the wind-erosion events into 15 levels. According to Jararah et al. (2020), wind-erosion modeling can help assess wind erosion rate; Models estimate erosion rates from small local scales to large geographical ones (Jararah et al., 2020, Blanco-Canqui \& Lal, 2008). Previous studies have identified the climatic and surface soil characteristics as two crucial factors involved in the mechanism of soil movement by the wind (Jararah et al., 2020; Khoshakhlagh et al., 2017; Refahi, 2004; Greeley et al., 1985; Chepil, 1959; Chepil et al., 1963; Bagnold, 1941).

The instability and mobility of dunes are a significant concern in the planning and managing the arid coastal plains; therefore, it is essential to study soil formation and development in such areas. According to the studies by the Iranian National Plan for the Identification of Crisis Centers of Wind Erosion, the western part of Makran coastal plains exposed to wind erosion (Desert Affairs Office, 2002) due to its topographic and soil characteristics (Asadpour \& Akbarian, 2009; Akbarian et al.,2008). This study attempted to identify the factors that affected the wind erosion potential and its temporal variations in the western part of Makran coastal plain as a dry coastal region.

\section{Observation area}

The study area is located in the western coastal plain of Makran, southern Iran at $25^{\circ} 32^{\prime} \mathrm{N}-25^{\circ} 50^{\prime} \mathrm{N}, 57^{\circ} 20^{\prime}-$ $59^{\circ} 00^{\prime} \mathrm{E}$, to the north of the Gulf of Oman (Figure 1). Generally, the area is dry and windy with very little rain but lots of sandstorms, torrents, thunderstorms, high humidity, and fog. Geologically, the site is affected by the general structure of the Makran Mountains and is mainly composed of shale, marl, and sandstone layers. Here the main rivers are seasonal. Most floods happen from late autumn to early spring accordingly. River beds are dry in summer when flooding is minimal. Along coastal plain delta, the direction and the beds of revers are changing. These hydrodynamic characteristics result in more granular deposits and allowing more wind erosion (Akbarian, 2019).

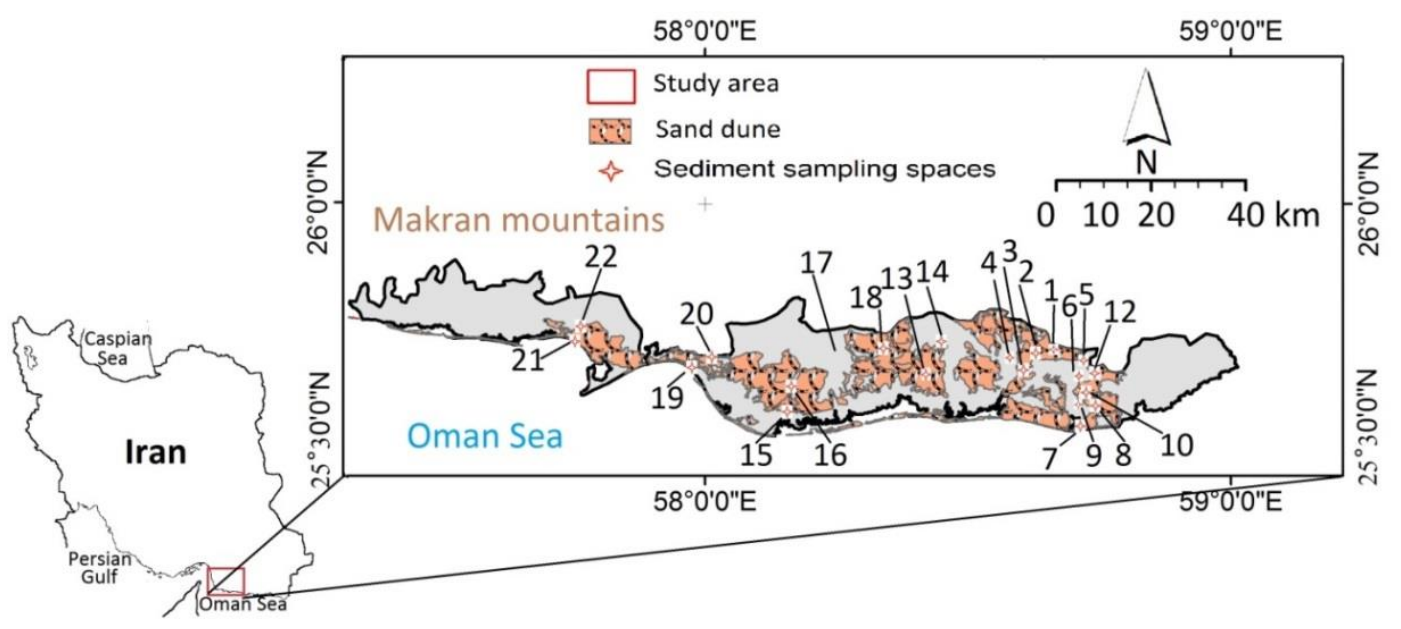

Figure 1: Location of the study area in the southeast of Iran. Surface soil sampling sites are marked with a sample code on the map.

\section{Material and methods}


The data collected and processed in this study include the wind velocities, relative humidity, and precipitation percentage from 1/1/1993 to 12/31/2018, and the granulometric information about the plain surface sediments: wind depositions, bed of dry rivers, and coastal plain landforms. The research tools included topographic and geomorphological maps of the area, GPS, laboratory instruments of granulometry, and sampling equipment.

The study was conducted in two steps as follows:

»Step 1: Estimation of threshold friction velocity

I) landforms characteristics

The first step in studying geomorphological forms is demonstrating them and their morphometric characteristics. Therefore, landforms are divided into the origin, transportation, and sedimentation areas from a wind erosion perspective. Other influential factors in wind erosion processes, including wind direction and plain topography, were also studied. In order to obtain wind characteristics such as the direction, magnitude, and speed of prevailing winds, WRplot software was used. Based on landforms' susceptibility to wind erosion, the wind rose diagrams and related information of the distribution map of landforms based on wind erosion sensitivity was obtained.

II) Sedimentological studies and threshold wind velocity in dry air conditions

There are many ways to estimate the threshold friction velocity in dry air conditions. The major references are the global research records (Bagnold, 1941; Zachar, 1982; Chepil, 1945, 1957, and 1959; Williams,1964) and local research records (Shayan et al., 2014; Akbarian, 2003; Akbarian, 2014 and Ekhtesasi, 2006) as well as the field observations of sand stabilization camps experts affiliated to the General Department of Natural Resources of Hormozgan Province (Akbarian, 2008; Akbarian, 2007). In this study, the wind velocity was estimated as a function of grain size and particle size (Table 1), as recommended by Zachar (1982) and Ahmadi (2008).

Table1: Threshold wind velocity in relation to grain size (Ahmadi, 2008; Zachar, 1982)

$\begin{array}{lll}\text { Statistical mode of grains' size }(\mu \mathrm{m}) & \begin{array}{l}\text { Threshold wind velocity at } 10 \mathrm{~m} \text { height } \\ \left(\mathrm{ms}^{-1}\right)\end{array} & \text { Soil erodibility } \\ 0.1-0.15 & 5-7 & \text { Very high } \\ 0.05-0.1 \text { and } 0.15-0.5 & 7-9 & \text { high } \\ 0.01-0.05 \text { and } 0.5-1 & 9-12 & \text { Medium } \\ 0.005-0.01 \text { and } 1-2 & 12-18 & \text { Low } \\ >2 \text { and }<0.005 & >18 & \text { Very low }\end{array}$

In order To study the granulation of surface soil particles, reference was made to the research records, the geomorphological maps of the studies conducted in the region (Figure 2), and susceptibility map of landforms to wind erosion(Figure 4). Then, sediment sampling points were determined. For this purpose, depending on the extent and distribution of sand masses, ten sites were selected in sedimentation areas. At each site, samples were taken at fixed distances throughout the whole area. Dunes were sampled at a maximum distance of $2 \mathrm{~km}$ from one another. At least three samples of the surface soil were taken from a depth of $3 \mathrm{~cm}$ in origin and transit areas. Likewise, the samples of rivers bed (current and dry ones) and the tidal zones were taken. In total, 22 samples were taken. The surface soil sampling sites were marked with a sample code on the map of the study area (Figure 1). Samples were sent to the laboratory for further measurements. 100 grams of sediments were weighed and sieved for 10 minutes by the shaker as a dry sieve. Then, ASTM classification was applied to granulate the sediment samples. The separated 
sediment samples were weighed on each sieve. Finally, the granulometric samples and the size characteristics of the particles were measured via the Gradistat.V.5 software. Wind erosion threshold velocity was determined as a function of the relationship between particle size (statistical mode of grains' diameters) and threshold velocity (Table 1).
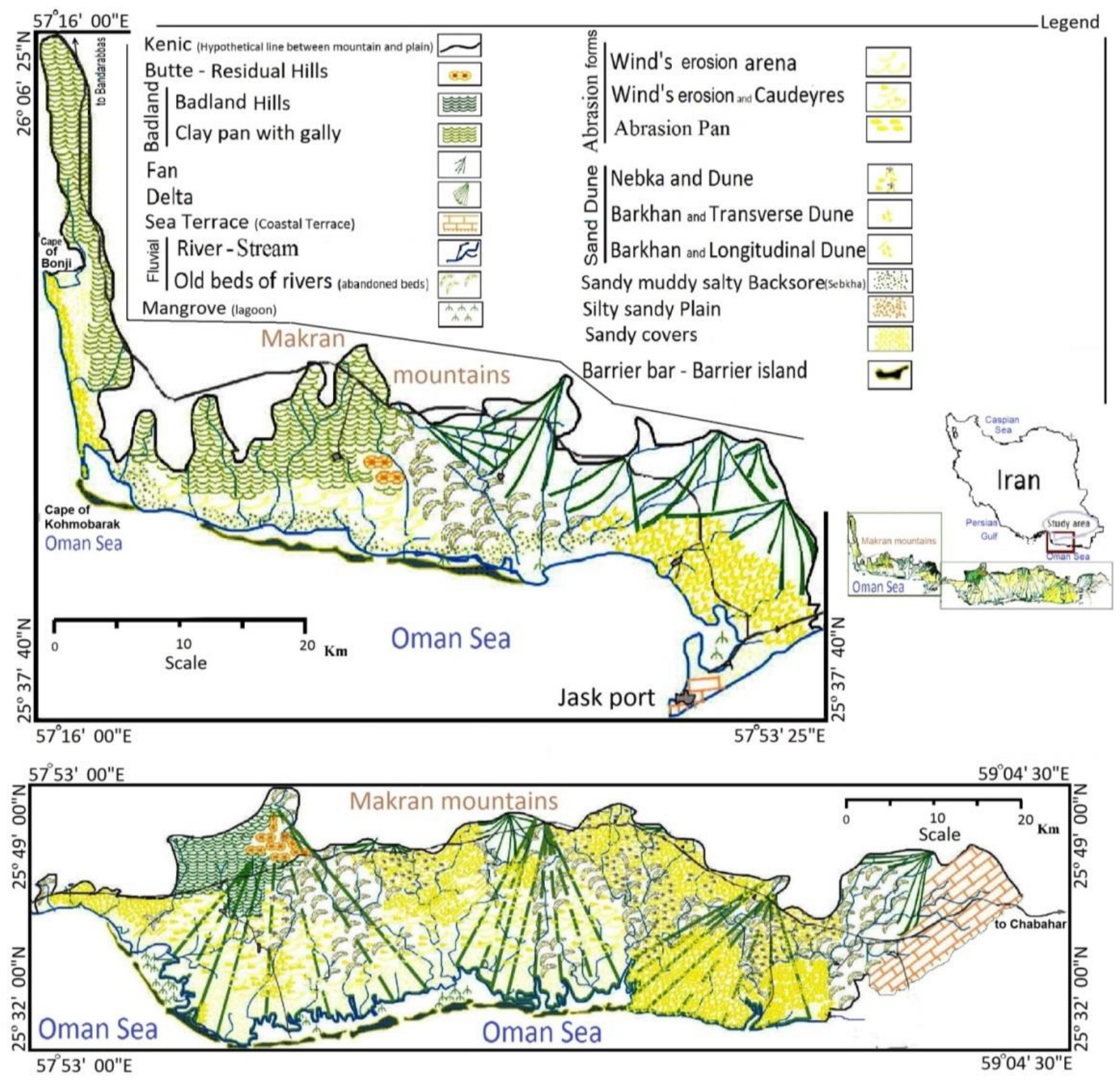

Figure 2: geomorphological map of Western Makran Coastal Plain(after Akbarian, 2014).

III) Threshold wind velocity in humid air conditions

The rate of erosion threshold increases, just as relative humidity does (Refahi, 2004). The threshold velocity in the humid air conditions was calculated based on the Belly (1964) equation (Equation 1).

Equation 1): $U_{t h}=\left(1+\frac{0.5 h}{100}\right) U_{i}$ 
Where $U_{\text {th }}$ is threshold velocity in the humid air conditions, (h) is humidity percentage, and $\left(U_{i}\right)$ is threshold velocity in the dry air conditions.

»Step 2: The probability of wind erosion

Based on the probability of wind blowing at speed exceeding the threshold velocity and the lack of moistureprecipitation necessary for soil adhesion, the following relationship was used to investigate the conditions of erosion probability from $1 / 1 / 1993$ to $12 / 31 / 2018$ (Equation 2). Since the threshold velocity is different for different landforms, the probability of wind erosion was calculated for the most sensitive forms.

Equation 2): $P(S / D)=\frac{P(S \cap D)}{P(D)}$

Where $\mathrm{P}(\mathrm{S} / \mathrm{D})$ is the likelihood of erosion, $\mathrm{P}(\mathrm{S} \cap \mathrm{D})$ is the conditional probability of the wind blowing at speed exceeding the threshold velocity and occurrence of Drought Days (DD), the Days with rainfall less than a millimeter, and P (D) is the DD. The cohesion between water molecules and soil particles causes soil particles to adhere to one another so that the wind cannot move them (Mesbahzadeh, 1389). Thus, the days with rainfall of less than a millimeter were considered as dry ones.

The parameters mentioned were calculated monthly and annually based on daily data in the Excel program. Accordingly, the probability of wind erosion in different months and changes in the probability of its occurrence during the selected period were calculated and analyzed using the Mann-Kendall test.

»Step 3: Temporal variability in wind erosion indicators

By interfering with precipitation, evaporation, and wind speed, it is possible to create indicators to determine the activity of dunes (wind erosion). One of these indicators, consistent with the data available from the study area, is the activity index of sand masses, developed by Lancaster (1988). Equation 3 shows how to calculate this index (Cooke et al., 1993; Lancaster, 1988).

Equation 3): $M=W /(P / E)$

Where $\mathrm{M}$ is an index of activity or mobility of the sand masses, $\mathrm{W}$ is the time percentage of the wind blowing at speed exceeding the threshold velocity. $\mathrm{P}$ and $\mathrm{E}$ are annual rainfall and potential evapotranspiration, respectively. Since the threshold velocity is different for different landforms (Table 3), the wind erosion threshold was considered for the most sensitive forms. According to the Lancaster Index, sand masses are divided into the following two categories. If $M>200$, it is an indicator of "highly active sand masses," and if $M<50$, it is an indication that "all sand masses are stabilized." In this step, to calculate the potential evapotranspiration, the evaporation pan data were utilized. Through the annual rainfall and wind erosion threshold in humid conditions (Table 4), the annual variability of sand mass mobility index was calculated and analyzed from 1/1/1993 to 31/12/2018.

\section{Results}

I) wind velocity threshold in dry and humid conditions

The only synoptic station that has the same topographic characteristics in the study area is the Jask station. Figure 3 shows the wind rose diagrams and frequency distribution of wind direction based on 25-year wind data. The prevailing wind is westerly. However, based on field study, it appears that dunes are moving in a northeasterly direction. The wind rose diagram at 12 GMT, the elongation of sand masses, and the lengthening of the coastal plain show that dunes being affected by a southwesterly wind accompanied by a sea breeze in the afternoons. 

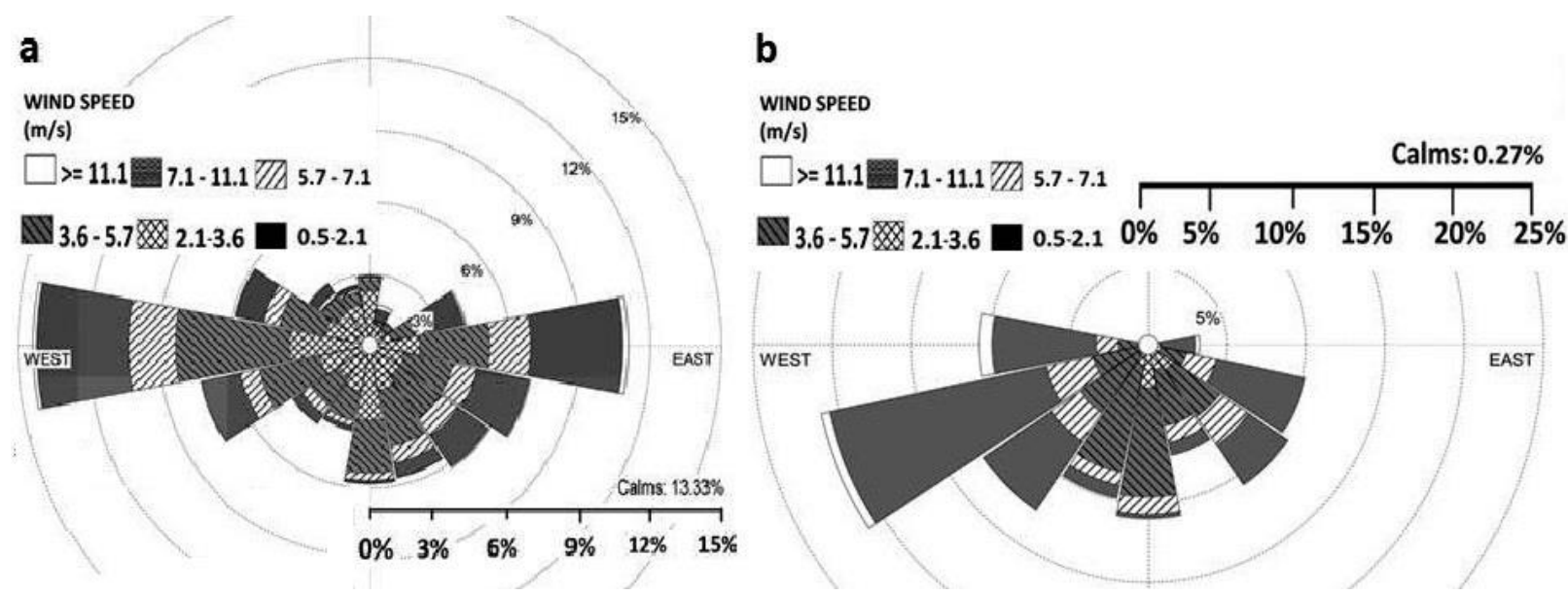

Figure 3: Wind roses, annual a) 12 GMT b

In the western plain of Makran, the widest landforms are old river beds, sandy backshores, and sand masses. Each landform shows a special rate of sensitivity to wind erosion. Table 2 and Figure 4 indicate the distribution of landforms based on wind erosion sensitivity.

Table 2: Distribution of landforms in western region of Makran coastal plain

\begin{tabular}{llll} 
landforms & \multicolumn{2}{c}{ Area } & Remarks \\
\cline { 2 - 3 } Erosion sheets (erosion crusts) & $\underline{\mathrm{km}^{2}}$ & $\underline{\%}$ & erosion arena \\
Sandy backshore & 45.59 & 1.82 & erosion arena \\
Old beds of rivers (abandoned beds) & 276.31 & 11.00 & erosion arena(partly) \\
Blew out (erosion rills) & 515.59 & 20.53 & erosion arena \\
Abrasion pan & 5.27 & 0.21 & eron \\
Erosion sheets \& transverse dunes & 37.82 & 1.51 & erosion arena( in dry condition) \\
Nebka & 300.28 & 11.96 & erosion arena \& transportation zone \\
Barrier bars- Barrier islands & 161.31 & 6.42 & transportation zone \\
Ancient sand masses & 34.78 & 1.39 & deposition zone \\
Sand masses & 4.46 & 0.18 & deposition zone \\
Fan & 298.26 & 11.88 & deposition zone \\
Clay pan with gully & 257.61 & 10.26 & partly resistant to wind erosion \\
Badland & 115.24 & 4.59 & partly resistant to wind erosion \\
Sandy muddy backshore & 46.31 & 1.84 & partly resistant to wind erosion \\
Lagoon (Mangrove) & 56.73 & 2.26 & partly resistant to wind erosion \\
Badland hills & 148.71 & 5.92 & resistant to wind erosion \\
Butte- residual Hills & 1.90 & 0.08 & resistant to wind erosion \\
Hillside & 27.34 & 1.09 & resistant to wind erosion \\
Sea terrace (coastal terrace) & 47.62 & 1.90 & resistant to wind erosion \\
Sann & 129.84 & 5.17 & resistant to wind erosion
\end{tabular}

Generally, Makran coastal plain can be divided into four groups of landforms elicited from wind erosion: 
A. sources of sediment for wind erosion (origin zone or erosion arena).

B. Landforms that act as sediment transportation areas (transportation zone).

C. The area of sedimentation of wind deposits (deposition zone).

D. Landforms that are resistant to wind erosion.

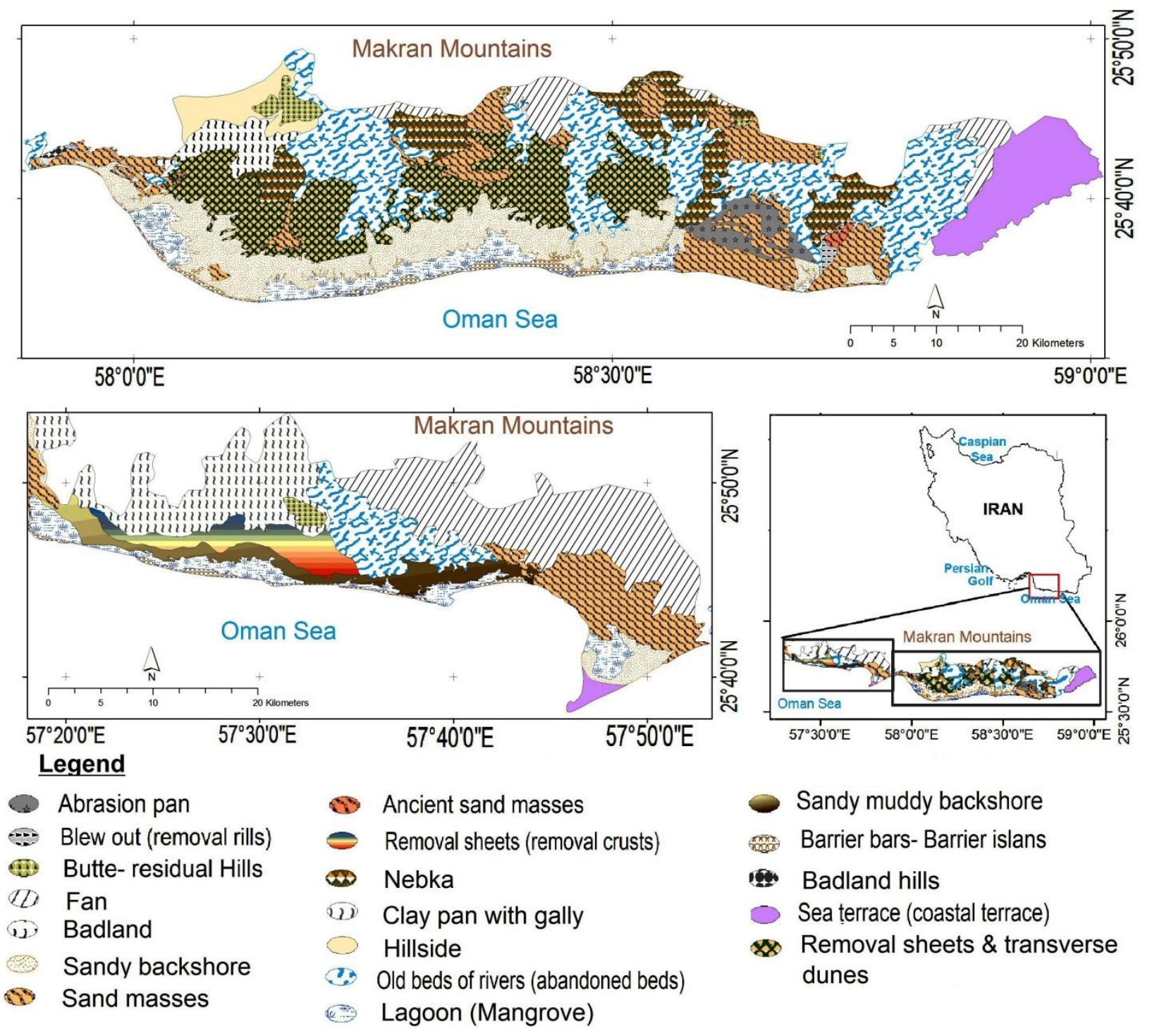

Figure 4: Makran coastal plain landforms based on their sensitivity to wind erosion

The statistical mode of grains' size of sediment particles in the research area varies between 94 and 375 micrometers (Table 2). Most of the lowland landscape sediments have a size of $187.57 \mu \mathrm{m}$, so the Zakhar table (Table 1) indicates the minimum threshold of wind erosion at a rate of $7.21 \mathrm{~ms}-1$ results in dry conditions (Table 3). 
Table 3, Sand masses' grain sedimentology and threshold wind velocity in dry air conditions

\begin{tabular}{llll}
$\begin{array}{l}\text { Sample } \\
\text { numbers }\end{array}$ & considerations & $\begin{array}{l}\text { statistical mode of } \\
\text { grains' size }(\mu \mathrm{m})\end{array}$ & $\begin{array}{l}\text { threshold wind } \\
\text { velocity }\left(\mathrm{ms}^{-1}\right)\end{array}$ \\
\hline 1 & Barkhan & 187.5 & 7.2 \\
2 & Barkhan & 187.5 & 7.2 \\
3 & Nebka & 94 & 7.2 \\
4 & River bed & 187.5 & 7.2 \\
5 & Nebka, Blew out & 94 & 7.2 \\
6 & Nebka & 94 & 7.2 \\
7 & Tidal zone & 187.5 & 7.2 \\
8 & Sand dune & 187.5 & 7.2 \\
9 & Blew out (wind erosion arena) & 187.5 & 7.2 \\
10 & Sand dune & 187.5 & 7.2 \\
11 & Nebka & 94 & 7.2 \\
12 & River bed & 187.5 & 7.2 \\
13 & Barkhan & 187.5 & 7.2 \\
14 & River bed & 94 & 7.2 \\
15 & Tidal zone & 94 & 7.2 \\
16 & Sand dune & 187.5 & 7.2 \\
17 & River bed & 375 & 8.3 \\
18 & Sand dune & 187.5 & 7.2 \\
19 & Tidal zone & 94 & 7.2 \\
20 & Sand dune & 375 & 8.3 \\
21 & Tidal zone & 187.5 & 7.2 \\
22 & Sand dune & 187.5 & 7.2
\end{tabular}

Table 4 shows the percentages of daily relative humidity and the changes in the rate of wind erosion threshold proportional to it, which were calculated based on the Belly (1964) equation from 1/1/1993 to 12/31/2018.

Table 4: Percentages of daily relative humidity and the changes in the rate of wind erosion threshold proportional to it on each samples, in the period from 1/1/1993 to 12/31/2018

\begin{tabular}{|c|c|c|c|c|c|c|c|c|}
\hline \multirow{2}{*}{$\begin{array}{l}\text { Sample } \\
\text { numbers }\end{array}$} & \multirow{2}{*}{$\begin{array}{l}\text { Grain size } \\
(\mathrm{mm})\end{array}$} & \multirow{2}{*}{$\begin{array}{l}\text { threshold wind } \\
\text { velocity dry air } \\
\text { conditions }\left(\mathrm{ms}^{-1}\right)\end{array}$} & \multicolumn{3}{|c|}{ relative humidity (\%) } & \multicolumn{3}{|c|}{$\begin{array}{l}\text { threshold wind velocity, } \\
\text { humid conditions }\left(\mathrm{ms}^{-1}\right)\end{array}$} \\
\hline & & & Min & Max & Mean & Min & Max & Mean \\
\hline 1 & 187.5 & 7.2 & 17.1 & 97 & 70.5 & 7.2 & 10.7 & 9.7 \\
\hline 2 & 187.5 & 7.2 & 17.1 & 97 & 70.5 & 7.2 & 10.7 & 9.7 \\
\hline 3 & 94 & 7.2 & 17.1 & 97 & 70.5 & 7.2 & 10.8 & 9.8 \\
\hline 4 & 187.5 & 7.2 & 17.1 & 97 & 70.5 & 7.2 & 10.7 & 9.7 \\
\hline 5 & 94 & 7.2 & 17.1 & 97 & 70.5 & 7.2 & 10.8 & 9.8 \\
\hline 6 & 94 & 7.2 & 17.1 & 97 & 70.5 & 7.2 & 10.8 & 9.8 \\
\hline 7 & 187.5 & 7.2 & 17.1 & 97 & 70.5 & 7.2 & 10.7 & 9.7 \\
\hline 8 & 187.5 & 7.2 & 17.1 & 97 & 70.5 & 7.2 & 10.7 & 9.7 \\
\hline 9 & 187.5 & 7.2 & 17.1 & 97 & 70.5 & 7.2 & 10.7 & 9.7 \\
\hline 10 & 187.5 & 7.2 & 17.1 & 97 & 70.5 & 7.2 & 10.7 & 9.7 \\
\hline 11 & 94 & 7.2 & 17.1 & 97 & 70.5 & 7.2 & 10.8 & 9.8 \\
\hline 12 & 187.5 & 7.2 & 17.1 & 97 & 70.5 & 7.2 & 10.7 & 9.7 \\
\hline 13 & 187.5 & 7.2 & 17.1 & 97 & 70.5 & 7.2 & 10.7 & 9.7 \\
\hline 14 & 94 & 7.2 & 17.1 & 97 & 70.5 & 7.2 & 10.8 & 9.8 \\
\hline 15 & 94 & 7.2 & 17.1 & 97 & 70.5 & 7.2 & 10.8 & 9.8 \\
\hline 16 & 187.5 & 7.2 & 17.1 & 97 & 70.5 & 7.2 & 10.7 & 9.7 \\
\hline 17 & 375 & 8.3 & 17.1 & 97 & 70.5 & 8.3 & 12.3 & 11.2 \\
\hline 18 & 187.5 & 7.2 & 17.1 & 97 & 70.5 & 7.2 & 10.7 & 9.7 \\
\hline 19 & 94 & 7.2 & 17.1 & 97 & 70.5 & 7.2 & 10.8 & 9.8 \\
\hline 20 & 375 & 8.3 & 17.1 & 97 & 70.5 & 8.3 & 12.3 & 11.2 \\
\hline 21 & 187.5 & 7.2 & 17.1 & 97 & 70.5 & 7.2 & 10.7 & 9.7 \\
\hline 22 & 187.5 & 7.2 & 17.1 & 97 & 70.5 & 7.2 & 10.7 & 9.7 \\
\hline
\end{tabular}


II) Wind erosion probabilities

According to the results (Figure 4), the highest probability of erosion is in February, March, and April with 24.69\%, $21.21 \%$, and $20.41 \%$, respectively, due to the simultaneous occurrence of drought and wind blowing at speed exceeding the threshold velocity. On the contrary, the lowest probability of wind erosion during the year is October, November, and September, with $4.00 \%, 4.12 \%$, and 6.00\%, respectively. In short, in the western Makran plain region, the highest probability of wind erosion is from February to May. On the contrary, the lowest probability of erosion is from mid-September to mid-December (Figure 5).

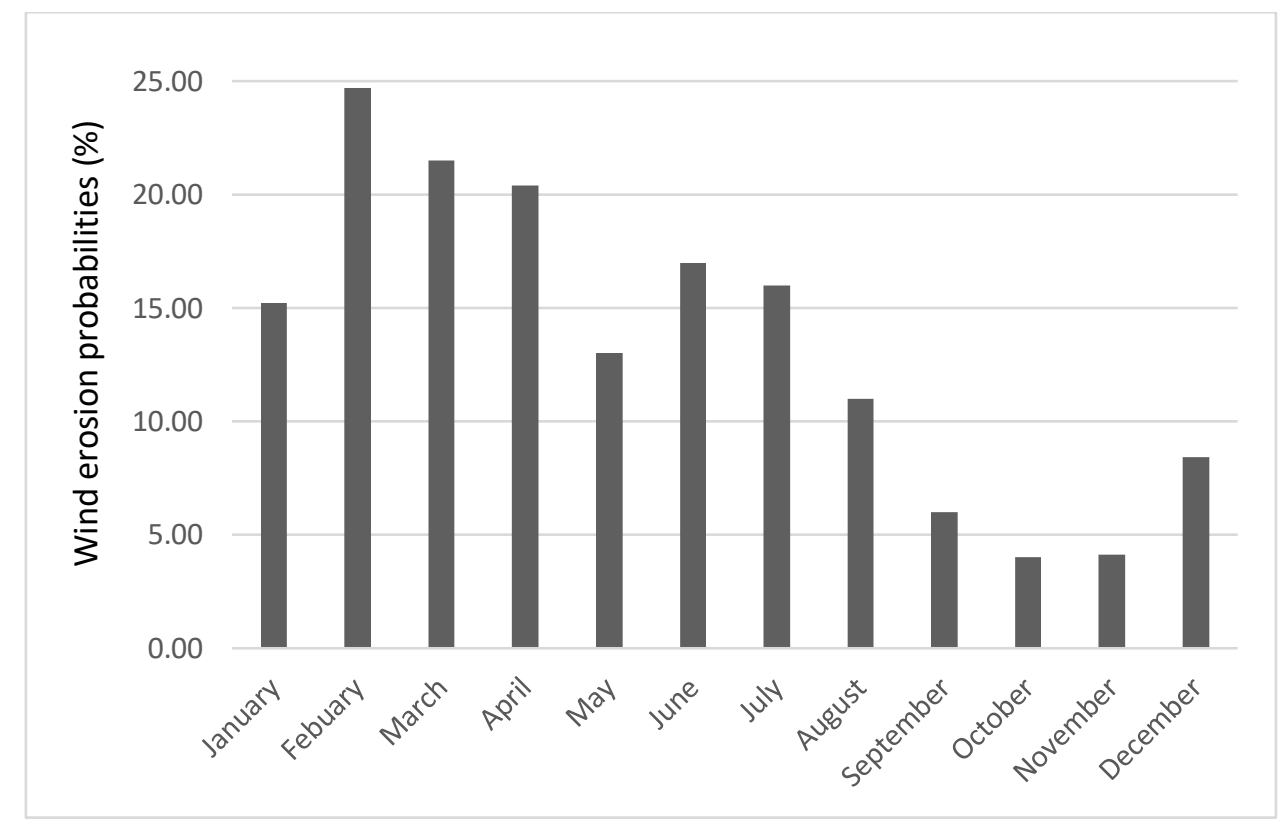

Figure 5: The probability of erosion based on the simultaneous occurrence of drought and wind blowing beyond the threshold velocity in different months (1/1/1993 to 31/12/2018)

Table 5 shows the results of the Mann-Kendall test on the factors involved in calculating the probability of annual erosion in the research region. Where $\mathrm{P}(\mathrm{S} / \mathrm{D})$ is the likelihood of erosion, $\mathrm{P}(\mathrm{S} \cap \mathrm{D})$ is the conditional probability of simultaneous winds and rainfall less than a millimeter, and P (D) is the probability of drought (less than one millimeter of precipitation). 
Table 5: The results of the Mann-Kendall test, the probability of annual and monthly erosion occurrence, and the trend of variability in the factors involved in the probability of erosion in the period from 1/1/1985 to 4/30/2015 in

Winds with rainfall less than a
millimeter
No trend
p-value $=0.032$
alpha $=0.05$
No trend
No trend
No trend
No trend
No trend
p-value $=0.009$
alpha $=0.05$
No trend
No trend
No trend
No trend
No trend

$\begin{array}{ccc}\begin{array}{c}\text { Occurrence of } \\ \text { droughtiness } \\ \text { No trend }\end{array} & \text { Occurrence of erosion } & \\ \text { No trend } & \text { No trend } & \text { Annual } \\ \text { No trend } & \text { alpha }=0.030 & \text { January } \\ \text { No trend } & \text { No trend } & \text { February } \\ \text { No trend } & \text { No trend } & \text { March } \\ \text { No trend } & \text { No trend } & \text { April } \\ \text { No trend } & \text { No trend } & \text { May } \\ \text { No trend } & \text { No trend } & \text { June } \\ \text { No trend } & \text { p-value }=0.008 & \text { July } \\ \text { No trend } & \text { alpha }=0.05 & \text { August } \\ \text { No trend } & \text { No trend } & \text { September } \\ \text { No trend } & \text { No trend } & \text { October } \\ \text { No trend } & \text { No trend } & \text { November } \\ & \text { No trend } & \text { Necember }\end{array}$

Figure 6 shows the Mann-Kendall test of annual occurrence of wind erosion, and Figure 7 indicates Mann-Kendall test s, the trend of variability in wind erosion, drought as well as drought and winds threshold velocities in January and July.

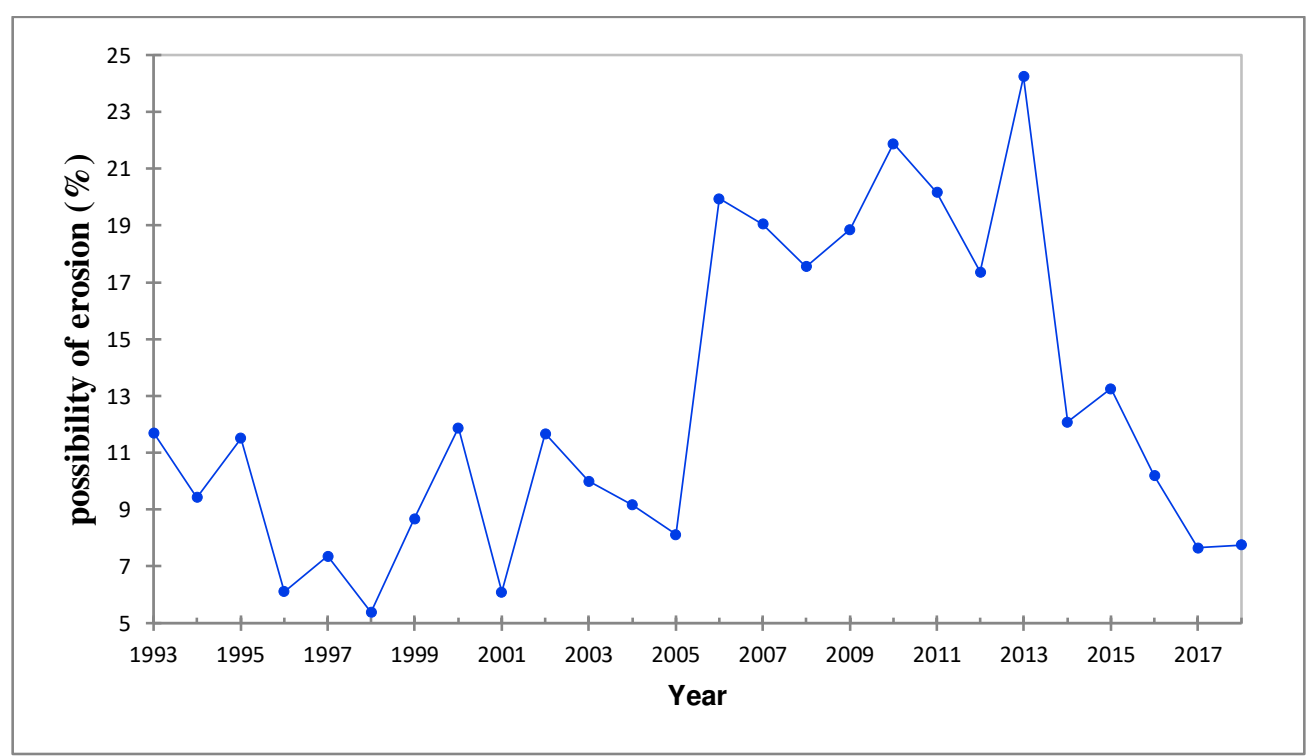

Figure 6: Mann-Kendall trend test, percentage of annual occurrence of wind erosion based on the simultaneous occurrence of winds with rainfall less than a millimeter 


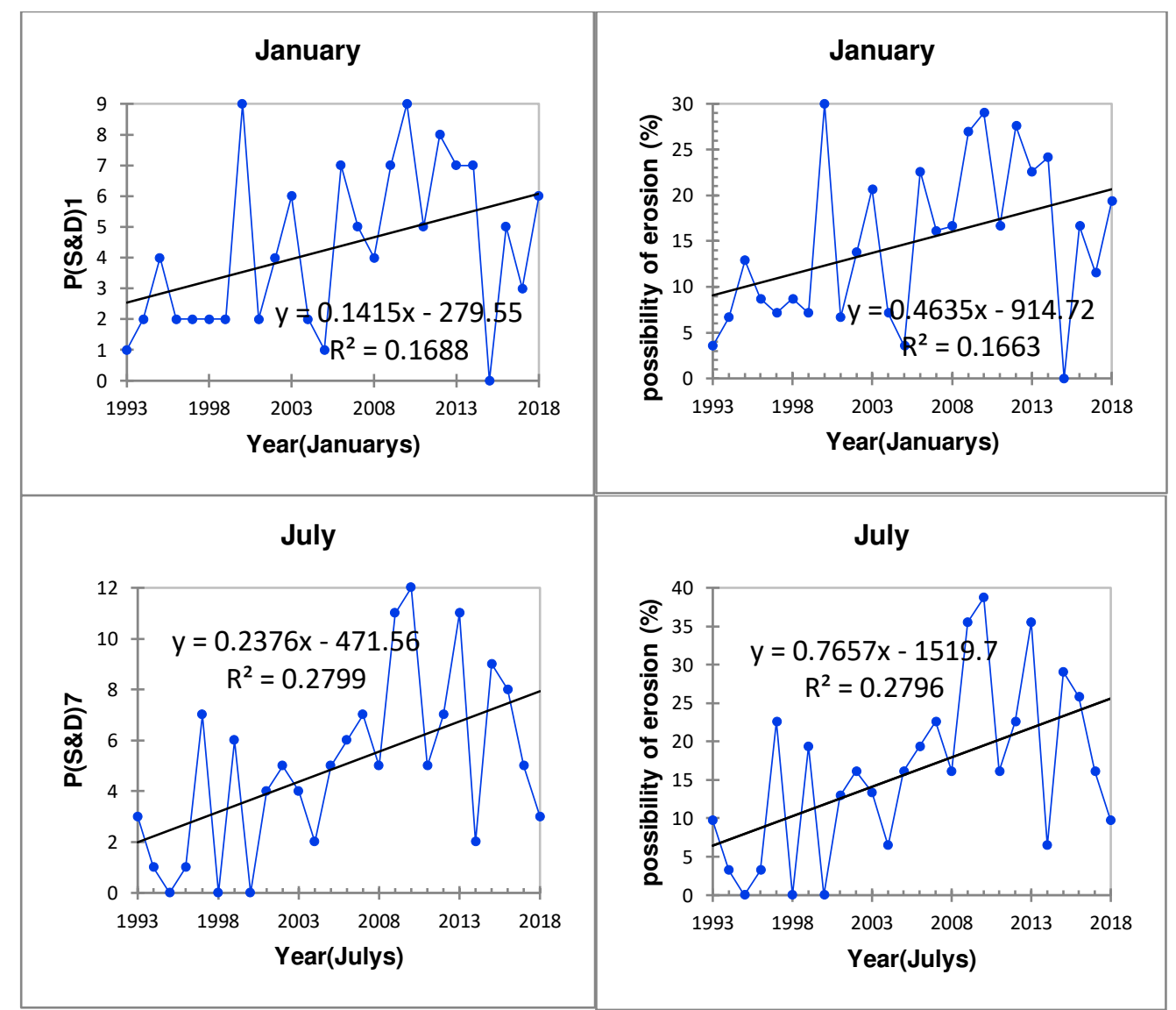

Figure 7: Mann-Kendall test, the trend of changes in wind erosion, dryness, dryness, and winds in January and July (1/1/1993 to 12/31/2018); Where $\mathrm{P}(\mathrm{S} \& \mathrm{D})$ is the percentage of winds simultaneous with rainfall less than one millimeter

III) Temporal variability in wind erosion indicators

Table 6 shows the statistical characteristics of the sand masses mobility index in the western part of Makran coastal plain. Also, Figure 8 illustrates its temporal variability.

Table 6: Statistical characteristics of the sand masses activity index in the western part of Makran plain from $1 / 1 / 1985$ to $30 / 4 / 2015$

\begin{tabular}{ccccc}
$\begin{array}{c}\text { Time percentage of wind } \\
\text { blowing higher than } \\
\text { threshold velocity }\end{array}$ & $\begin{array}{c}\text { Annual potential } \\
\text { evapotranspiration } \\
(\mathrm{mm})\end{array}$ & $\begin{array}{c}\text { Annual rainfall } \\
(\mathrm{mm})\end{array}$ & $\begin{array}{c}\text { Index of activity } \\
\text { or mobility }\end{array}$ & \\
12.9 & 2343.8 & 104.5 & 288.6 & Average \\
24.7 & 3263.4 & 513.8 & 1941.8 & Max \\
5.8 & 1564.3 & 8.4 & 66.4 & Min \\
\hline
\end{tabular}




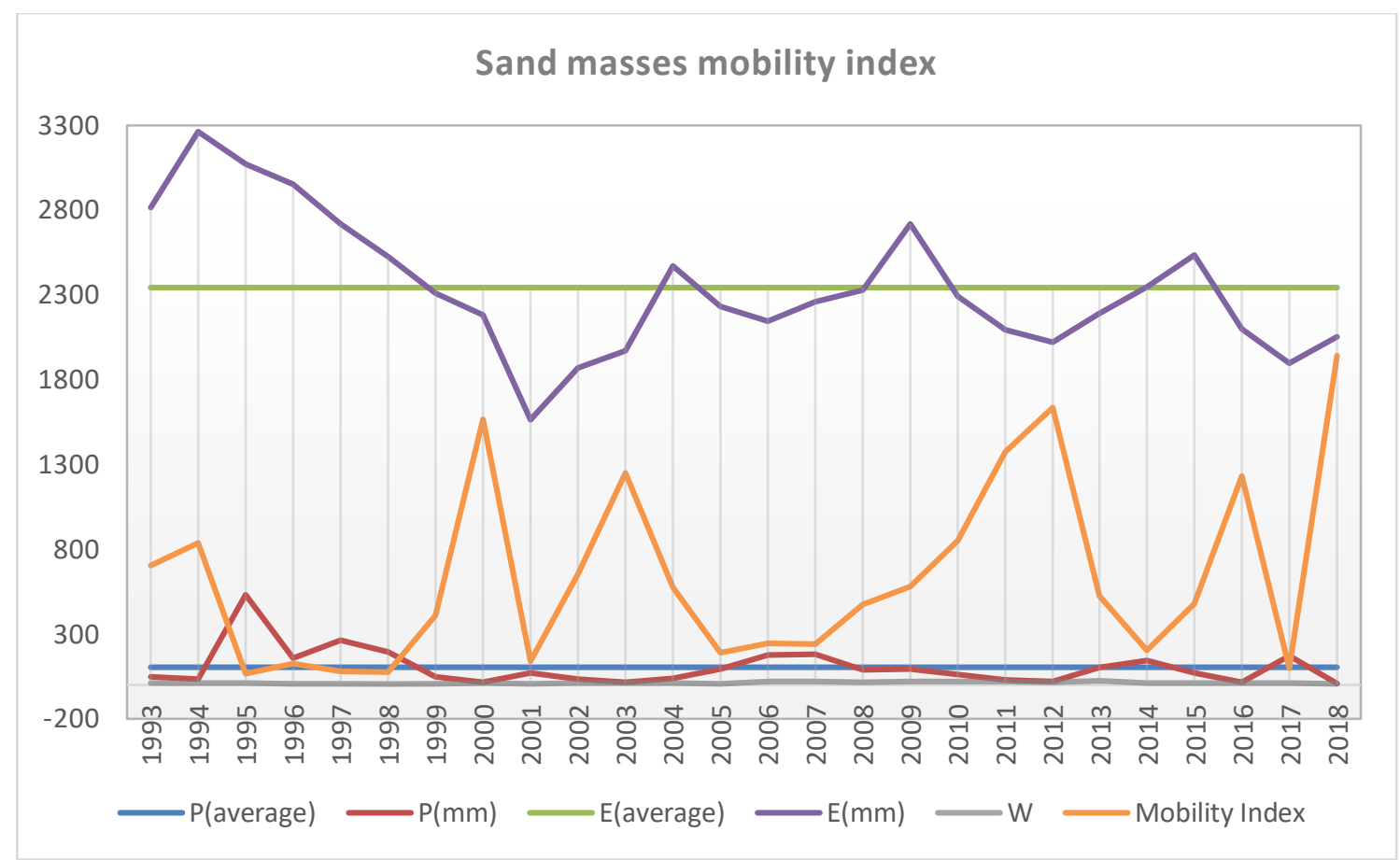

Figure 8: Temporal variability in the sand masses mobility index in the western part of Makran coastal plain from $1 / 1 / 1985$ to $30 / 4 / 2015$

Where $\mathrm{M}$ is the index of activity or mobility, $\mathrm{W}$ is the time percentage of wind blowing at speed exceeding the threshold velocity. $\mathrm{P}$ and $\mathrm{E}$ are annual rainfall and potential evapotranspiration, respectively.

\section{Discussion}

Concerning relative humidity changes, the wind erosion threshold varied between 7.21 and 12.31 meters per second during the research period. This variability is based on soil texture and humidity changes. The findings of soil texture are consistent with other researchers who have studied the soil texture Makran plain from the perspective of wind erosion (Barkhordari et al., 2005; Nohegar \& Yamanni, 2006; Nohegar et al., 2011; Asadpour \& Akbarian, 2019; Akbarian, 2014). Although surface soil characteristics of the region make it so sensitive to wind erosion, rainfall can increase the erosion threshold up to 12.31 meters per second. Therefore, the lack of rainfall will expose an extensive area to wind abrasion. Due to the lack of rainfall In the Makran plain, the highest and lowest probability of wind erosion was from February to May and September to December.

According to the findings, the average probability of annual wind erosion in Makran plain is $12.85 \%$, the maximum is $24.23 \%$, and the minimum probability of annual occurrence is $5.38 \%$. The lowest annual and the highest wind erosion occurred from 1996 to 1999 and from 2006 to 2013, respectively. The temporal variability index for mobility indicates a strong inverse relation to annual precipitation. Therefore, in the years with precipitation higher than average, the index has fallen sharply, and in the years when precipitation is lower than the annual average, the index has increased. Although the sensitivity of topsoil to wind erosion varies throughout the year in proportion to the amount of rainfall in different months, the probability of annual wind erosion in Makran plain does not indicate a significant trend. Based on Mann-Kendall test Annual data of DD and Above Threshold Winds Speeds (ATWS), 
there are no significant trends for the Makran plain. Consequently, it seems that global warming could affect some other wind erosion characteristics (IPCC,2007)more than the Annual data of DD.

Some previous studies have concentrated on the effects of global warming and climate change on wind erosion and reveal a complex relation (Hagen \& Woodruff, 1973; Fryrear, 1985; Sharratt et al., 2013; Sharratt et al., 2015). In addition, it is suggested that droughts intensity, frequency, and the area will be increasing under climate change scenarios, resulting in vegetation reduction and exposing the soil to wind erosion. Most studies focus on increasing wind erosion due to increasing temperature or decreasing rainfall and loss of vegetative cover under a changing climate (Gao et al. 2002; Liddicoat et al., 2012; Ashkenazy et al., 2011). This study presents that wind erosion in the western plain of Makran (Iran) will be mainly affected by increased wind speed frequency above the threshold at certain times of the year. Monthly trend analysis suggests that there was a significant increasing trend in wind erosion in January (winter solstice) and July (summer solstice). This increase is a result of the coincidence of DF and wind speed conditions. In other months, no relationship was found between the factors mentioned above.

According to the results, if the current trend is stabilized in early winter and early summer, ATWS will increase and will lead to more abrasion and consequently dust events at these times. Climate change will negatively impact soil erosion by increasing surface susceptibility and driving forces, such as the amount, timing, and erosive energy of precipitation and wind (Edwards et al., 2019). Not only climate change causes soil susceptibility to erosion, as other studies show (Edwards et al., 2019; Sharratt et al., 2015; Sharratt et al., 2013; Fryrear, 1985), but it also alters the erosive factor (wind) and looks like it will cause an increasing trend of erosion in certain months. From this perspective, it is necessary to focus on the increase in wind occurrence coinciding with winter and summer solstice in future studies.

\section{Conclusion}

In conclusion, by increasing the erosive energy, climate change has negative impacts on wind erosion in the western region of Makran coastal plain, Iran. The erosion trend analysis indicates that wind erosion is a temporal phenomenon that increases significantly in January (winter solstice) and July (summer solstice). These months are characterized by an increase in the wind blowing at speed above the threshold; Otherwise, they are not different from the others in precipitation or the number of dry days. Therefore, wind erosion is expected to maximize in the early winter and the early summer due to increased wind blowing speed.

\section{Declarations}

\section{- Conflicts of interest:}

We confirm that this work is original and has not been published elsewhere, nor is it currently considered for publication elsewhere.

\section{- Funding Statement:}

We have no funding for this research.

\section{- Authors' contributions:}

Two authors contributed to this paper. It is mentioned in the contribution section of the manuscript.

- Availability of data and material 
The data and materials are clarified in the material and methods section of the manuscript. Data will be made available on reasonable request.

\section{- Code availability:}

All custom codes are available.

\section{- Ethics approval:}

Not applicable

\section{- Consent to participate:}

All authors agree to participate, submit and publish the paper.

\section{- Consent for publication:}

All authors agree to submit and publish the paper.

\section{Refrences}

1- Abbasi, H. R., Opp, C., Groll, M., Rohipour, H., Gohardoust, A., 2019. Assessment of the distribution and activity of dunes in Iran based on mobility indices and ground data, Aeolian Research, Volume 41, https://doi.org/10.1016/j.aeolia.2019.07.005Get rights and content

2- Ahmadi, H., 2008. Applied geomorphology, vol.2: Desert, Tehran: University of Tehran Press.

3- Akbarian, M. 2014. Analysis of Coastal plain Sand Masses Morphogenesis and their temporal variations (Case study: Western coast of Makran), Dissertation Submitted in Partial Fulfillment of the Requirements for the Degree of Doctor of Philosophy (Ph.D) in Physical Geography (Geomorphology), Supervisors: Dr. Shayan S. and Dr. Yamanni M., Tarbiat Modares University, Tehran, Iran, 168 pages

4- Akbarian, M., 2003. Supplemental report on erosion and sedimentation of for sand stabilization and desertification plan of Chenali - Sedich and Biahi. Bandar Abbas: General Department of Natural Resources of Hormozgan Province, Iran.

5- Akbarian, M., 2007, Performannce Report of the Hormozgan Combating Desertification Office. Bandar Abbas: Department of Natural Resources of Hormozgan Province, Iran.

6- Akbarian, M., 2008, Daily report of natural events in sand stabilization projects area of Jask county, Department of Natural Resources and Watershed Mannagement of Hormozgan province, Iran.

7- Akbarian, M., Biniaz, M., 2011. Evaluation of plant species used in wind erosion control (Case study: Jask county, Hormozgan province, Iran). Journal of Environmental Erosion Research. 1: 2, p29-42.

8- Akbarian, M., Kaboli, S. H., Moradi, N., 2012. Comparison of water and wind erosion performannce in arid land degradation (Case study: Jeyhun plain, Hormozgan province, Iran). Journal of Rangeland and Watershed Mannagement, Iranian Journal of Natural Resources, 65: 4, p443-448.

9- Akbarian, M., Shayan, S., Yamanni, M., 2018. Analysis of Coastal Rivers Dynamics on Tidal Zone Sedimentological Characteristics and Transition, Case study: Western Mokran Coastal Plain, Physical Geography Research, 50: 1, p 57-68. 
10- Asadpour, R., Akbarian, M., 2018. Morphogenesis of sand masses and its relationship with vegetative components of Sphaerocoma aucheri, Case study: Coastal plain of Hormozgan province, Quantitative geomorphological researches, 7:4, p93-104.

11- Asakareh, H., Khoshraftar, R., Mousavi, S. K., 2015. Study of wind erosion probabilistic in Khuzestan, BiQuarterly Journal of Desert Geographical Exploration, No. 6, 1-13.

12- Bagnold, R.A., 1941. The Physics of Blown Sand and Desert Dunes. Methuen, London. 265p.

13- Barkhordari, J., Akbarian, M., Khosrowshahi, M., 2005. Determining the Territory of Desert Areas of Hormozgan Province with Emphasis on Geomorphology, Second National Conference on Watershed Soil and Water Resources Mannagement, Kermann, Iran.

14- Bird, E., 2008. Coastal Geomorphology An Introduction, Wiley, 436p.

15- Chepil, W.S., Woodruff, N.P. (1963). The physics of wind erosion and its control. Advances in Agronomy 15, 211-302.

16- Chorley, R. J., Schumm, S. A., Sugden, D. E., 2000. Geomorphology, Volume 3: Slope, waterway, coastal and wind processes. Translated by Motamed, A., Tehran: Samt Publications.

17- Cooke, R., Warren, A., Goudie, A., 1993. Desert Geomorphology, UCL Press, St. Ives.

18- CORNELIS W.M. (2006) HYDROCLIMATOLOGY OF WIND EROSION IN ARID AND SEMIARID ENVIRMONMENTS. In: D'Odorico P., Porporato A. (eds) Dryland Ecohydrology. Springer, Dordrecht. 141159

19- Cornelis, W.M., D. Gabriels and R. Hartmannn (2004b). A conceptual model to predict the deflation threshold shear velocity as affected by near-surface water content: 2. Calibration and Verification. Soil Sci. Soc. Am. J.. $68,1162-1168$.

20- Desert Affairs office, Tak Sabz Agricultural Development and Rehabilitation Consulting Engineers Company, 2002, Identification Plan of wind erosion Critical center of Hormozgan Province, Forests, Rangelands and Watershed Mannagement Organization.

21- Edwards, B.L., Webb, N.P., Brown, D.P., Elias, E., Peck, D.E., Pierson, F.B., Williams, C.J., Herrick, J.E., 2019. Climate change impacts on wind and water erosion on US rangelands. Journal of Soil and Water Conservation. 74. 405-418. doi:10.2489/jswc.74.4.405

22- Ekhtesasi, M. R., 2006, Sedic-Heimann Crisis Center Control Plan, Volume 4: Erosion and Sediment Studies, Bandar Abbas: Department of Natural Resources of Hormozgan Province.

23- Fryrear, D.W., 1985. Soil cover and wind erosion. Trans. Am. Soc. Agric. Eng. 28, 781-784.

24- Gao, Q., Ci, L., Yu, M., 2002. Modeling wind and water erosion in northern China under climate and land use changes. J. Soil Water Conserv. 57, 46-55.

25- Greeley, R., Iversen, J.D. 1985. Wind as a Geological Process on Earth, Mars, Venus and Titan. Cambridge Planetary Science Series. Cambridge University Press, Cambridge.

26- Hagen, L., Woodruff, N.P., 1973. Air pollution from dust storms in the Great Plains. Atmos. Environ. 7, 323332. 
27- Hanifehpour, M., Mashhadi, N., Khosravi, H., 2013. T The Effect of Intensity and Duration of Drought on Wind Conditions and Wind Erosion in Agricultural Areas (Case Study: Damghan Area), journal of Environmental Erosion Research, 3(2): 65-77.

28- IPCC. 2013. Climate change, 2013. The physical science basis. In: Stocker, T.F., Qin, D., Plattner, G.-K., Tignor, M., Allen, S.K., Boschung, J., Nauels, A., Xia, Y., Bex, V., Midgley, P.M. (Eds.), Contribution of Working Group I to the Fifth Assessment Report of the Intergovernmental Panel on Climate Change. Cambridge University Press, Cambridge, United Kingdom, p. 1535.

29- Jararah, M., Mayel, S., Tatarco, J., Funk, R., Kuka, K., 2020. A review of wind erosion models: Data requirements, processes, and validity, Catena, www.elsevier.com/locate/catena,187: 1-16.

30- Khoshakhlagh F, Moradimoghadam M, Mohamadi H, Mahoutchi M., 2017. Assessing the Effects of Global Warming on the Areas Susceptible to Wind Erosion in the West of Central Plains and the East of Central Zagros Mountains of Iran, journal of Environmental Erosion Research, 7 (2): 43-58

31- Kidd, R. 2001. Coastal Done Mannagement, A Mannual of Coastal Dune Mannagement and Rehabilitation Techniques, NSW Department of Land and Water Conservation, 96p.

32- Lancaster, N., 1988. Development of linear dunes in the southwestern Kalahari, souther Africa. Journal of Arid Environments 14, 44-233.

33- Larson, M., Erikson, L. and Hanson, H. 2004. An analytical model to predict dune erosion due to wave impact. Coastal Engineering, Vol. 51, p. 675-696

34- Larson, M., Erikson, L. and Hanson, H., 2004. An analytical model to predict dune erosion due to wave impact. Coastal Engineering, Vol. 51, p. 675-696

35- Liddicoat, C., Haymann, P., Alexander, B., Rowland, J., Maschmedt, D., Young, M.-A., Hall, J., Herrmannn, T., Sweeney, S., 2012. Climate change, wheat production and erosion risk in South Australia's cropping zone: linking crop simulation modelling to soil landscape mapping. Government of South Australia, Department of Environment, Water and Natural Resources.

36- Mahmoodi, F., 1989. Dynamic geomorphology, Tehran: Payam-e-Noor press.

37- Mahmoodi, F., 2002. Geographical distribution of Sand seas in Iran. Tehran: Research Institute of Forests and Rangelands.

38- Mesbahzadeh, T., Ahmadi, H., Nowruzi, A. A., Rostami, M., 2010. Investigation of the intensity of wind erosion in Abuzidabad, Kashan. Second National Conference on Wind Erosion. Yazd: Scientific Association for Mannagement and Control of Desert Areas of Iran.

39- Morgan, R. P. C. 2009. Soil Erosion and Conservation, Third Edition, John Wiley \& Sons, 320 pages.

40- Murthy, C.R., Sinha, P.C., Rao, Y.R., 2002, Modeling and Monitoring of Coastal Marine Processes, Springer, $249 \mathrm{p}$

41- Nohegar, A., Abbas zadeh F., Akbarian M., Hatami Gorbandi, H., 2011. Investigation of Polylatise Polymer Capability in Soil Conservation against Wind Erosion, Case Study: Gahrdo Sirik, Journal of Environmental Erosion Research, 1 (3): 5-15

42- Refahi, H.G., 2004. Wind erosion and its control. Tehran: University of Tehran Press. 
43- Rijn, Leo C. van. 2013. EROSION OF COASTAL DUNES DUE TO STORMS, www.leovanrijn-sediment.com

44- Sharratt, B.S., Tatarko, J., Abatzoglou, J.T., Fox, F.A., Huggins, D., 2015. Implications of climate change on wind erosion of agricultural lands in the Columbia plateau. Weather and Climate Extremes. 10, 20-31.

45- Sharratt, B.S., Vaddella, V.K., Feng, G., 2013. Threshold friction velocity influenced by wetness of soils within the Columbia Plateau. Aeol. Res. 9, 175-182.

46- Shayan, S., Akbarian, M., Yamanni,M., Sharifikia, M., Maghsoudi, M., 2016. Dominant processes causing the Formation of Coastal Sand Masses, Case study: Western Makran Coastal Plain, Volume 15, Issue 2, P 97-114

47- Shayan, S., Akbarian, M., Yamanni,M., Sharifikia, M., Maghsoudi, M., 2014. Affect of Sea Hydrodynamic on Coastal Sand Masses Formation, Case study: Western Makran Coastal Palin, Quantitative Geomorphological Research, 2(4): 86-104.

48- Shen, Y., Zhang, C., Wang, X., Kang, L. 2018. Statistical characteristics of wind erosion events in the erosion area of Northern China, Catena, 167, 399-410.

49- Sirjani, E., Sameni, A., Moosavi, A.A., Mahmoodabadi, M., Laurent, B., 2019. Portable wind tunnel experiments to study soil erosion by wind and it's like to soil properties in the Fars Province Iran, Geoderma, $333,69-80$.

50- Steetzel, H., 1993. Cross-shore transport during storm surges. Doctoral Thesis, Delft University of Technology, Delft, The Netherlands

51- Wilson S.J. and Cook R.U., 1980. Wind erosion. In: Soil Erosion (Eds M.J. Kirkby, R.P.C. Morgan). Wiley, Chichester, 217-251.Yan, P., Shi, P., 2004. Using the 137CS Technique to Estimate Wind Erosion in Gonghe Basin, Qinghai Province, China, Soil Science, VOL. 169 No. 4, 295-305

52- Zachar, D. 1982. Soil erosion. Developments in Soil Science 10. Amsterdam: Elsevier Scientific. 547 pp. 